Pteridines

Vol. 1, 1989, pp. $119-124$

\title{
Correlation of Serum Interferon Gamma and Neopterin Concentrations in Africans with Various Diseases*
}

By Gilbert Reibnegger ${ }^{1}$ ), Dietmar Fuchs ${ }^{1}$ ), Arno Hausen ${ }^{1}$ ), Erich Schmutzhard ${ }^{2}$ ), Ernst R. Werner ${ }^{1}$ ), Gabriele Werner-Felmayer ${ }^{1}$ ), Manfred P. Dierich ${ }^{3}$ ) and Helmut Wachter ${ }^{1}$ )

:) Institut für Medizinische Chemie und Biochemie, Universität Innsbruck

$\left.{ }^{2}\right)$ Universitätsklinik für Neurologie, Universität Innsbruck

${ }^{3}$ ) Institut für Hygiene, Universität Innsbruck

$\left.{ }^{1}\right)^{3}$ ) Ludwig-Boltzmann-Institut für AIDS-Forschung, Innsbruck

Fritz-Pregl-Str. 3, A-6020 Innsbruck, Austria

(Received November 1988)

\section{Summary}

Concentrations of interferon gamma in serum and of neopterin in serum and urine were determined in 55 Tanzanians attending a local hospital for various diseases or complaints. For comparison, serum concentrations of interferon gamma and of neopterin were also measured in 76 clinically healthy Austrian blood donors. Both interferon gamma and neopterin concentrations were significantly higher in patients than in blood donors. Both analytes were significantly correlated with each other, and both exhibited similar behaviour in dependence on clinical diagnosis. The results support use of neopterin determination for indirect measurement of endogenous production of interferon gamma.

\section{Introduction}

Recent research on the activation of human macrophages has provided conclusive evidence that a specific $\mathrm{T}$ lymphocyte product, interferon gamma, plays a key role in activation, and thus in the regulation, of the cell-mediated immune response (1). The many facets of the interaction between the lymphokine and its cellular target, the human mononuclear phagocyte, and its importance in host defense mechanisms have been recently summarized (2).

Neopterin, a pyrazino-[2,3-d]-pyrimidine compound, is biosynthesized from guanosine triphosphate (GTP) (3). It was shown in vitro that the activation of human peripheral blood mononuclear cells by alloantigens or by chemically or virally modified self structures leads to release of neopterin into culture supernatants $(4$, 5). Human monocytes/macrophages were shown to release large amounts of this pterin upon stimulation

\footnotetext{
* This work was financially supported by the Austrian Bundesministerium für Wissenschaft und Forschung, Sektion Forschung.

Enzyme: GTP cyclohydrolase I (EC 3.5.4.16)
}

with interferon gamma (6). Recently, the enzyme GTP-cyclohydrolase I which catalyzes the conversion of GTP to the key intermediate for pteridine biosynthesis, 7,8-dihydroneopterin triphosphate, was demonstrated to be induced in peripheral blood mononuclear cells by interferon gamma (7).

In vivo, a multitude of studies has revealed the clinical value of neopterin measurement as a means to assess the activation of cell-mediated immune reactions (for review, see e.g. ref. 8). Very few studies, however, have directly investigated the relationship between endogenously circulating interferon gamma and neopterin $(9,10)$. The present investigation was performed to further assess the correlation between interferon gamma and neopterin in vivo. As part of an epidemiological investigation, we have determined serum concentrations of interferon gamma and serum and urinary concentrations of neopterin in a group of Tanzanians attending a rural hospital due to a variety of different diseases or complaints. For control purposes, serum concentrations of interferon gamma and neopterin were also measured in healthy Austrian blood donors. 


\section{Materials and Methods}

\section{Patients}

Serum and urine specimens were analyzed from 55 subjects out of 253 Tanzanian patients attending a rural hospital in Karagwe District, Bukoba region, Tanzania. These 253 individuals were enrolled in a study on epidemiological and clinical characteristics related with retroviral infections. A full account of this larger study will be published elsewhere (11). The selection of the 55 individuals was made solely on the fact that there was absolutely no evidence of hemolysis in their sera which is a prerequisite for the interferon gamma radioimmunological determination. There were 22 men and 33 women; mean age was 32 years ( $\mathrm{SD}=14.1$ years) and age range was from 10 to 64 years. Details of clinical and serological diagnostic methods are being published elsewhere (11). For the 55 subjects included in this study, the following diagnoses were made: 3 patients with acquired immunodeficiency syndrome (AIDS), 3 with antibodies to HTLV-1, 21 patients with malaria (2 were also seropositive for anti-HIV-1), 2 with tuberculosis, 2 with clinical signs of viral infection (no definitive identification of the agent done), 12 patients with various skeletal and skin diseases or anemia or autoimmune diseases who showed clinical evidence of active immunological and inflammatory processes, and finally 12 subjects with various symptoms and minor complaints in whom active immunological processes were not very likely. It must be stressed that the classification of the latter 24 patients was made solely on clinical grounds, based on history, signs and symptoms. Laboratory diagnostic facilities were extremely limited.

For control, concentrations of interferon gamma and neopterin were also determined in 76 unselected apparently healthy subjects who voluntarily donated blood to the Red Cross Blood Donation Service of the Austrian Tyrol and the donations of whom were subjected to the usual laboratory tests at the Department for Blood Transfusion and Immunology at the University Hospital of Innsbruck, Austria. There were 47 men and 29 women, mean age was 33 years (SD $=12.1$ years) and age range was from 18 to 64 years. All donors had passed the usual anamnestic and physical examination prior to donation, none was found to be seropositive for anti-HIV-1, for surface antigen of hepatitis B virus, for antibodies to syphilis, and none had an alanine aminotransferase concentration exceeding $35 \mathrm{U} / \mathrm{L}$.

\section{Interferon gamma assay}

Interferon gamma was determined using an immunoradiometric assay (Centocor Inc., Malvern, PA) in a modified version (12) which allows the detection of the lymphokine in serum with sufficient sensitivity. The detection limit is $18 \mathrm{U} / \mathrm{L}$ (expressed in NIH units). Briefly, beads coated with monoclonal antibody to human interferon gamma were incubated at room temperature with $200 \mu \mathrm{L}$ serum for 16 hours. Then the beads were washed with $3 \mathrm{~mL}$ distilled water and incubated for further 16 hours with $200 \mu \mathrm{L}$ tracer labeled with iodine-125. With this modified procedure more than $80 \%$ of the analyte is bound to the solid phase antibody. Radioactivity was counted in a gamma counter. Concentrations exceeding $100 \mathrm{U} / \mathrm{L}$ were classified as being raised (12).

\section{Neopterin assay}

In serum, neopterin was quantified by radioimmunoassay (RIAcid, Henning-Berlin, Berlin, FRG). Fifty $\mu \mathrm{L}$ serum were incubated with $100 \mu \mathrm{L}$ of polyclonal neopterin antiserum for 1 hour at room temperature and for 1 further hour with neopterin tracer labeled with iodine-125. Two $\mathrm{mL}$ of a solution of $60 \mathrm{~g} / \mathrm{L}$ polyethyleneglycol (PEG 6000) were added, and, after centrifugation at $2000 \mathrm{~g}$ for $10 \mathrm{~min}$, radioactivity was counted in a gamma counter. The detection limit is $1 \mathrm{nmol} / \mathrm{L}$, and the results obtained with this method compare well with results from high pressure liquid chromatography (HPLC) (13). Concentrations exceeding $8.7 \mathrm{nmol} / \mathrm{L}$ in adults and $13.5 \mathrm{nmol} / \mathrm{L}$ in children below 18 years of age were classified as being raised (13).

In urine, neopterin was determined by a reversedphase HPLC technique (Model LC 5500; Varian Associates, Palo Alto, CA) described elsewhere (14) with slight modifications. Briefly, $100 \mu \mathrm{L}$ urine was mixed with $1 \mathrm{~mL}$ aqueous dihydrogenphosphate/hydrogenphosphate buffer $(15 \mathrm{mmol} / \mathrm{L}, \mathrm{pH}=6.4)$ containing $5.4 \mathrm{mmol} / \mathrm{L}$ ethylene diamine tetraacetate. Ten $\mu \mathrm{L}$ of diluted urine were injected by an autosampling device (Model 8000; Varian Associates) onto the analytical system consisting of a guard column (Hibar LiChroCart, $4 \times 4 \mathrm{~mm}$; E. Merck, Darmstadt, FRG), packed with $7 \mu \mathrm{m} \mathrm{C}$-18 material (LiChroSorb, RP18; E. Merck) and an analytical column (Hibar LiChroCart, $125 \times 4 \mathrm{~mm}$ ) packed with the same material. Elution was performed with degassed dihydrogenphosphate/hydrogenphosphate buffer (15 $\mathrm{mmol} / \mathrm{L}, \mathrm{pH}=6.4$ ) at $25^{\circ} \mathrm{C}$ and a flow rate of 0.8 $\mathrm{mL} / \mathrm{min}$. Neopterin was detected by its native fluorescence (Fluorichrom; Varian Associates) at an excitation wavelength of $353 \mathrm{~nm}$ and emission wave- 
length of $438 \mathrm{~nm}$. Simultaneously, creatinine was detected by UV absorption at $235 \mathrm{~nm}$ (UV 200; Varian Associates). Neopterin concentrations were related to creatinine to compensate for physiological variations of urine concentrations. and were expressed as $\mu \mathrm{mol}$ neopterin per mol creatinine. The method was fully automated, the performance criteria have been published elsewhere (14).

Urinary neopterin concentrations observed in 417 healthy adults and in 143 children and normal ranges based on these results have been reported elsewhere $(14,15)$. These were used for defining raised concentrations in this work.

\section{Statistical procedures}

Since concentrations of interferon gamma and of neopterin did not follow a Gaussian distribution in the patients, nonparametric methods and data transformations were used. For medians of biochemical variables, differences between patients subgroups were tested for by Mann-Whitney $U$ test. The intervariable correlations were estimated using Spearman's rank correlation method, and by regression analysis after logarithmic transformation of data. Frequencies of raised concentrations were compared using Fisher's exact test based upon $2 \times 2$ contingency tables. Chisquare tests were used for comparison of classified variables.

\section{Results}

Serum concentrations of interferon gamma and of neopterin in 55 Tanzanian patients and in 76 healthy Austrian blood donors are shown in Table 1. Blood donors showed concentrations of both analytes fitting very well into previously determined normal ranges. In contrast. the Tanzanian patients exhibited significantly higher concentrations of interferon gamma (Mann-Whitney U-statistic $=142,5, \mathrm{p}<0.0001)$ and of neopterin $(U=181.5, p<0.0001)$. Similarly, the frequencies of raised concentrations of both compounds were significantly higher $(\mathrm{p}<0.0001$; Fisher's exact test) in the patients than in blood donors.

Table 2 shows concentrations of interferon gamma in serum and of neopterin in serum and in urine of patients classified according to diagnoses. The same trend is visible for both compounds: Concentrations were high in patients with AIDS and infections with viruses, with parasites as Plasmodium falciparum and with intracellular facultative bacteria as Mycobacterium tuberculosis, in subjects with antibodies to HTLV-1 and in patients with signs of active immunological processes. In patients with various com-
Table 1. Interferon gamma $(\mathrm{U} / \mathrm{L})$ and serum neopterin $(\mathrm{nmol} / \mathrm{L})$ concentrations in study participants.

\begin{tabular}{llc}
\hline & $\begin{array}{l}\text { Healthy } \\
\text { Controls } \\
(\mathrm{N}=76)\end{array}$ & Patients \\
& $(\mathrm{N}=55)$ \\
\hline $\begin{array}{l}\text { Interferon gamma } \\
\quad \text { Range })\end{array}$ & $\begin{array}{l}\left.23.5(1.7)^{\mathrm{a}}\right) \\
\text { Interquartile range }\end{array}$ & $\left.199(15.9)^{\mathrm{a}}\right)$ \\
$\quad 18-34$ & $18-2416$ \\
above 100 U/L & $3 / 76(3.9 \%)$ & $132-268$ \\
Serum neopterin & $\left.5.7(0.12)^{\mathrm{a}}\right)$ & $25.55(87.3 \%)$ \\
$\quad$ Range & $3.1-17.1$ & $5.3-103.3$ \\
$\quad$ Interquartile range & $4.7-6.55$ & $12.8-41.6$ \\
$\quad$ above 8.7 nmol/L & $5 / 76(6.6 \%)$ & $46 / 55(83.6 \%)$ \\
Proportions with raised & $0 / 76(0.0 \%)$ & $42 / 55(76.4 \%)$ \\
interferon gamma and & & \\
serum neopterin concen- & & \\
trations & & \\
\hline
\end{tabular}

) Median (SE)

1) Detection limit $18 \mathrm{U} / \mathrm{L}$. Interferon gamma results below this limit are recorded as $18 \mathrm{U} / \mathrm{L}$ in the tables; Figure 1 shows the actual results of the measurements.

plaints and diseases in which activation of cell-mediated immunity was not very likely, concentrations were lower although they were raised in a significant proportion of subjects when being compared with blood donors.

When combining results from blood donors and from patients, there was a strong correlation between serum levels of interferon gamma and of neopterin (Spearman's rank correlation coefficient $=0.70$, $\mathrm{p}<0.0001)$. For the 55 patients alone, there were significant correlations between serum and urinary neopterin (rank correlation coefficient $=0.79$, $p<0.0001$ ), between serum interferon gamma and serum neopterin (rank correlation coefficient $=0.45$, $\mathrm{p}=0.0009$ ) and between serum interferon gamma and urinary neopterin (rank correlation coefficient $=0.47, \mathrm{p}=0.0005$ ).

Figure 1 shows the results obtained in the patients and in the blood donors. Linear regression analysis of the logarithmically transformed data showed in good agreement with the rank correlation analysis a linear correlation coefficient of $0.47(\mathrm{p}=0.0003)$ between serum neopterin and interferon gamma in the subgroups of the 55 patients, whereas in blood donors the correlation coefficient was practically zero $(\mathrm{r}=-0.05, \mathrm{p}=0.66)$. The regression analysis in the patients yielded the regression equation

$\log ($ neopterin $)=0.43 * \log ($ interferon $)+0.38$.

Table 3 shows results of Chi-square tests for the relationship between serum neopterin and interferon gamma concentrations. A very strong degree of association was invariably found between both analytes regardless of the chosen limits for classification. 
Table 2. Concentrations of interferon gamma and of neopterin in serum and in urine from Tanzanian patients in dependence on clinical diagnosis.

\begin{tabular}{|c|c|c|c|c|c|}
\hline \multirow[t]{2}{*}{ Diagnosis } & \multirow[t]{2}{*}{ Number } & \multirow{2}{*}{$\begin{array}{l}\operatorname{Sex} \\
(\mathrm{m} / \mathrm{f})\end{array}$} & \multirow{2}{*}{$\begin{array}{l}\text { Interferon } \\
\text { gamma }(\mathbf{U} / \mathbf{L})\end{array}$} & \multicolumn{2}{|l|}{ Neopterin } \\
\hline & & & & $\begin{array}{l}\text { serum } \\
(\mathrm{nmol} / \mathrm{L})\end{array}$ & $\begin{array}{l}\text { urine } \\
(\mu \mathrm{mol} / \mathrm{mol} \text { creatinine })\end{array}$ \\
\hline $\begin{array}{c}\text { Malaria } \\
\text { range } \\
\text { raised }\end{array}$ & 21 & $6 / 15$ & $\begin{array}{l}\left.228^{\mathrm{a}}\right) \\
88-1540 \\
20 / 21\end{array}$ & $\begin{array}{l}38.4 \\
17.9-103.3 \\
21 / 21\end{array}$ & $\begin{array}{l}1361 \\
244-2993 \\
21 / 21\end{array}$ \\
\hline $\begin{array}{l}\text { AIDS } \\
\text { range } \\
\text { raised }\end{array}$ & 3 & $3 / 0$ & $\begin{array}{l}\left.228^{a}\right) \\
139-2416 \\
3 / 3\end{array}$ & $\begin{array}{l}48.1 \\
16.3-77.2 \\
3 / 3\end{array}$ & $\begin{array}{l}1669 \\
963-1744 \\
3 / 3\end{array}$ \\
\hline $\begin{array}{c}\text { HTLV-1 } \\
\text { range } \\
\text { raised }\end{array}$ & 3 & $1 / 2$ & $\begin{array}{l}\left.196^{\mathrm{a}}\right) \\
124-728 \\
3 / 3\end{array}$ & $\begin{array}{l}24.1 \\
15.1-48.8 \\
3 / 3\end{array}$ & $\begin{array}{l}1102 \\
293-2665 \\
3 / 3\end{array}$ \\
\hline $\begin{array}{l}\left.\text { virus, } T b c^{b}\right) \\
\text { range } \\
\text { raised }\end{array}$ & 4 & $0 / 4$ & $\begin{array}{l}\left.385^{a}\right) \\
119-1887 \\
4 / 4\end{array}$ & $\begin{array}{l}34.6 \\
10.2-63.0 \\
4 / 4\end{array}$ & $\begin{array}{l}1190 \\
324-2517 \\
4 / 4\end{array}$ \\
\hline $\begin{array}{l}\text { miscellaneous') } \\
\text { range } \\
\text { raised }\end{array}$ & 12 & $7 / 5$ & $\begin{array}{l}\left.184^{\mathrm{a}}\right) \\
18-582 \\
8 / 12\end{array}$ & $\begin{array}{l}21.7 \\
5.4-63.0 \\
10 / 12\end{array}$ & $\begin{array}{l}584 \\
242-994 \\
12 / 12\end{array}$ \\
\hline $\begin{array}{l}\text { miscellaneous }{ }^{\mathrm{d}} \text { ) } \\
\text { range } \\
\text { raised }\end{array}$ & 12 & $5 / 7$ & $\begin{array}{l}\left.145^{\mathrm{a}}\right) \\
88-300 \\
10 / 12\end{array}$ & $\begin{array}{l}7.6 \\
5.3-14.7 \\
5 / 12\end{array}$ & $\begin{array}{l}209 \\
119-434 \\
7 / 12\end{array}$ \\
\hline
\end{tabular}

a) Median level

b) 2 patients with viral disease, 2 patients with lung tuberculosis

c) Miscellaneous diseases, signs for immunological activation apparent

d) Miscellaneous diseases or complaints, no immunological signs apparent

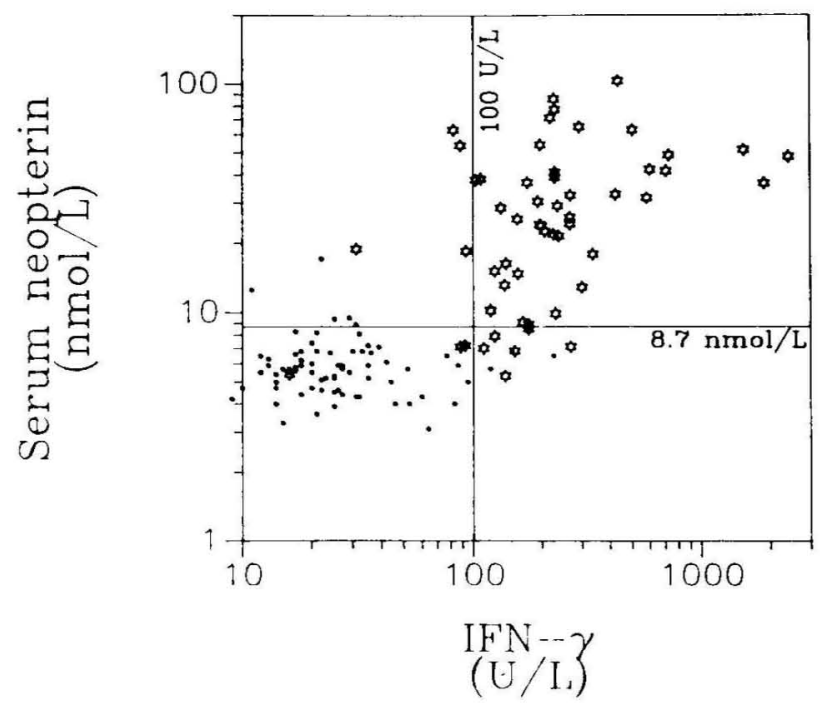

Figure 1. Correlation between serum concentrations of interferon gamma and neopterin in 76 healthy Austrian blood donors (small dots) and in 55 Tanzanian patients (stars). The lines indicate the upper limits of the normal range; i.e., $100 \mathrm{U} / \mathrm{L}$ interferon gamma and $8.7 \mathrm{nmol} / \mathrm{L}$ neopterin.
Table 3. Associations between interferon gamma $(U / L)$ and serum neopterin $(\mathrm{nmol} / \mathrm{L})$ concentrations by analysis of frequencies.

a) Classification by upper tolerance limits (shown are frequencies).

\begin{tabular}{lccr}
\hline & Neopterin & & \\
\cline { 2 - 4 } & below 8.7 & above 8.7 & total \\
\hline Interferon & & & \\
below 100 & 71 & 9 & 80 \\
above 100 & 9 & 51 & 51 \\
total & 80 & 131
\end{tabular}

Analysis: Chi-square $=66.2, \mathrm{p}<0.0001$

b) Classification by quartiles (Q; see Table 1) of distributions (shown are frequencies)

\begin{tabular}{|c|c|c|c|c|c|}
\hline & \multicolumn{5}{|c|}{ Neopterin } \\
\hline & Q1 & Q2 & Q3 & Q4 & total \\
\hline \multicolumn{6}{|c|}{ Interferon } \\
\hline Q1 & 16 & 15 & 4 & 0 & 35 \\
\hline Q2 & 14 & 9 & 8 & 0 & 31 \\
\hline Q3 & 7 & 6 & 13 & 7 & 33 \\
\hline Q4 & 0 & 1 & 6 & 25 & 32 \\
\hline total & 37 & 31 & 31 & 32 & 131 \\
\hline
\end{tabular}

Analysis: Chi-square $(9$ degrees of freedom $)=88.6, p<0.0001$. 


\section{Discussion}

Concentrations of interferon gamma in serum of humans are generally much lower than those found in cell culture conditions. The concentrations found in this study fit very well into the range of concentrations reported in transplant recipients (9) and sarcoidosis patients (10). Certainly these relatively low serum concentrations were responsible for the failure of earlier investigations to detect interferon gamma in serum of patients when employing bioassays or conventional radioimmunoassays with detection limits of about $1000 \mathrm{U} / \mathrm{L}$ or $200 \mathrm{~L}$ L. respectively.

This study has demonstrated a high degree of association between endogenous concentrations of interferon gamma and neopterin. The results are in good agreement with previcus in vitro experiments $(4-7)$. They extend results obtained in recipients of renal allografts (9) in whom raised concentrations of serum interferon gamma and neopterin were found during episodes of viral infection. or in patients with pulmonary sarcoidosis where high concentrations of both compounds were seen in active disease (10). Furthermore, the present study provides strong evidence that the raised neopterin concentrations reported earlier in various clinical conditions such as AIDS (16), malaria (17) or tuberculosis (18) were in fact due to the presence of endogenous interferon gamma, most likely produced by antigenically stimulated $\mathrm{T}$ cells. These data seem to contrast the in vitro experience of diminished interferon gamma production by $\mathrm{T}$ cells isolated from patients with these diseases (2). As proposed earlier, we believe that the reduced responsiveness of immune cells from AIDS patients in vitro is not representative for the in vivo situation, rather, it may be a result of continuous challenge of immune cells by antigens in vivo $(19,20)$. In agreement with observations on HIV-infected homosexuals (21) the results of the present investigations at least seem to put more weight to the suggestion that early events of the $\mathrm{T}$ lymphocyte/macrophage interplay are activated in AIDS patients, and that interferon gamma is endogenously raised in these patients (19.20).

Subjects infected with HTLV-1 exhibited both raised neopterin concentrations and raised concentrations of interferon gamma in a very high proportion. This appears to be consistent with the observation that the interferon gamma gene is actively transcribed in HTLV-1 infected cells, and interferon gamma, besides other cytokines such as interleukin-2, may be involved in growth control of this agent (22).

As Austrian blood donors were used as control group in the present study on Tanzanian patients, a possible effect of ethnic differences on interferon gamma and neopterin concentrations cannot be ruled out with certainty. However, such an effect is not very likely to be present: earlier studies $(16,17)$ on healthy individuals from the U.S.A. and from Thailand have demonstrated the same range of normal neopterin concentrations as found in Austrian healthy subjects.

This study supports use of neopterin as a convenient tool to measure endogenous interferon gamma production as there is a strong association between both compounds. The correlation is certainly not perfect which is not too surprising if one takes into account the different formation and degradation rates of both compounds in the organism as well as their different physico-chemical characteristics, e. g. size of the molecules. For practical reasons, there are several advantages to measure neopterin concentration in comparison with direct measurement of interferon gamma: Interferon gamma is metabolically rapidly degraded whereas neopterin, once being synthesized by macrophages in response to interferon gamma, is metabolically stable. Neopterin can be measured in serum as well as in urine thus allowing also frequent measurements without additional burden for patients. In allograft recipients it was shown that neopterin serum concentrations are a more sensitive indicator of acute graft rejection than interferon gamma, and it was concluded that interferon gamma produced locally in an organ does not readily enter the blood stream whereas neopterin, a small molecule with molecular mass of 253 Dalton, diffuses rapidly into the circulation where it is easily measurable (9). Finally, measurement of neopterin is much more rapidly done $(10$ minutes per sample with HPLC, 3 hours with radioimmunoassay) than the interferon gamma assay which requires two 16 hour incubation steps.

\section{References}

1. Nathan, C. F., Murray, H. W., Wiebe, M. E. \& Rubin, B. Y. (1983) J. Exp. Med. 158, 670-689.

2. Murray, H. W. (1988) Ann. Intern. Med. 108, 595-608.

3. Nichol, C. A., Smith, G. K. \& Duch, D. S. (1985) Ann. Rev. Biochem. 54, 729-764.

4. Fuchs, D., Hausen, A., Huber, C., Margreiter, R., Reibnegger, G., Spielberger, M. \& Wachter, H. (1982) HoppeSeyler's Z. Physiol. Chem. 363, 661-664.

5. Huber, C., Fuchs, D., Hausen, A., Margreiter, R., Reibnegger, G., Spielberger, M. \& Wachter, H. (1983) J. Immunol. 130, 1047-1050.

6. Huber, C., Batchelor, J. R., Fuchs, D., Hausen, A., Lang, A., Niederwieser, D., Reibnegger, G., Swetly, P., Troppmair, J. \& Wachter, H. (1984) J. Exp. Med. 160, 310-316.

7. Schoedon, G., Troppmair, J., Adolf, G., Huber, C. \& Niederwieser, A. (1986) J. Interferon Res. 6, 697-703.

8. Fuchs, D., Hausen, A., Reibnegger, G., Werner, E. R., Dierich, M. P. \& Wachter, H. (1988) Immunol. Today 9, $150-155$ 
9. Woloszczuk, W., Troppmair, J., Leiter, E., Flener, R., Schwarz, M., Kovarik, J., Pohanka, E., Margreiter, R. \& Huber, C. (1986) Transplantation 41, 716-719.

10. Woloszczuk, W., Köhn, H. D., Pohl, W. \& Klech, H. (1987) In: Biochemical and Clinical Aspects of Pteridines, Vol. 5. (Pfleiderer, W., Wachter, H. \& Blair, J. A., eds.) pp. $279-$ 287, Walter de Gruyter, Berlin - New York.

11. Schmutzhard, E., Fuchs, D., Hengster, P., Hausen, A., Hofbauer, J., Pohl, P., Rainer, J., Reibnegger, G., Tibyampansha, D., Werner, E. R., Dierich, M. P., Gerstenbrand, F. \& Wachter, H. (1989) Am. J. Epidemiol., in press.

12. Woloszczuk, W. (1985) Clin. Chem. 31, 1090.

13. Werner, E. R., Bichler, A., Daxenbichler, G., Fuchs, D., Fuith, L. C., Hausen, A., Hetzel, H., Reibnegger, G. \& Wachter, H. (1987) Clin. Chem. 33, 62-66.

14. Hausen, A., Fuchs, D., König, K. \& Wachter, H. (1982) J. Chromatogr. 227, $61-70$.

15. Reibnegger, G., Fuchs, D., Hausen, A., Kostron-Krainz, C. \& Wachter, H. (1984) Tumor Diagn. Ther. 5, 234-237.
16. Wachter, H., Fuchs, D., Hausen, A., Huber, C., Knosp, O., Reibnegger, G. \& Spira, T. (1983) Hoppe-Seyler's Z. Physiol. Chem. 364, 1345-1346.

17. Reibnegger, G., Boonpucknavig, V., Fuchs, D., Hausen, A., Schmutzhard, E. \& Wachter, H. (1984) T. Roy. Soc Trop. Med. Hyg. 78, 545-546.

18. Fuchs, D., Hausen, A., Kofler, M., Kosanowski, H., Reibnegger, G. \& Wachter, H. (1984) Lung 162, 497-500.

19. Fuchs, D., Hausen, A., Hengster, P., Reibnegger, G., Schulz, T., Werner, E. R., Dierich, M. P. \& Wachter, H. (1987) Science 235, 356.

20. Wachter, H., Fuchs, D., Hausen, A., Reibnegger, G., Werner, E. R. \& Dicrich, M. P. (1986) Lancet $i i, 1216-1217$.

21. Harrer, T., Messing, K., Bienzle, U., Meyer, E., Giedl, J \& Kalden, J. R. (1987) Klin. Wochenschr. 65, 864-872.

22. Arya, S. K. \& Gallo, R. C. (1985) Proc. Natl. Acad. Sci. USA $82,8691-8695$. 